\title{
Effect of Work Commitment, Supervision, and Discipline on the Quality of Work of Employees at PT. Bintang Saudara Semesta Jaya
}

\author{
Hendra Jonathan Sibarani ${ }^{1}$, Dennis Choandy ${ }^{2}$, Suriyani Halim ${ }^{3}$ \\ 1,2,3 Universitas Prima Indonesia, Indonesia \\ Corresponding Author: Hendra Jonathan Sibarani
}

\begin{abstract}
The purpose of this study was to determine the effect of work commitment, supervision, and discipline on the quality of work of employees of PT. Bintang Saudara Semesta Jaya, either partially or simultaneously. This research approach is based on a quantitative approach. This type of research is a type of quantitative descriptive research. The population of this study are all employees of PT. Bintang Saudara Semesta Jaya, which based on data obtained in October 2021, totaled 61 employees from all divisions except managers. The sampling technique used a saturated sample so that the sample used was representative of the entire population, namely 61 people. The data analysis technique used is multiple linear analysis technique. Hypothesis testing by means of Simultaneous partial ( $\mathrm{t}$ test), ( $\mathrm{F}$ test), and coefficient of determination (R2). The results of the study indicate that there is effect of work commitment on the quality of work of employees at PT. Bintang Saudara Semesta Jaya. There is effect of supervision on the quality of work of employees at PT. Bintang Saudara Semesta Jaya. There is effect of discipline on the quality of work of employees at PT. Bintang Saudara Semesta Jaya. Simultaneously there are effect of work commitment, supervision, and discipline on the quality of work of employees at PT. Bintang Saudara Semesta Jaya. The results of the regression calculation can be seen that the coefficient of determination ( $\mathrm{R}$ square) obtained is 0.409 , this result means that $40.9 \%$ of the quality of work of employees can be explained by the work commitment, supervision, and discipline, while the remaining $59.1 \%$ is
\end{abstract}

explained by other variables which is not researched.

Keywords: Work Commitment, Supervision, Discipline, Quality of Work, Employees

\section{INTRODUCTION}

The development and competition of medical devices is one of the biggest challenges for companies to survive in increasing sales of health products owned by the company. Human resources owned by the company are one of the spearheads in improving the quality of employee work so that companies need to pay attention to employee work commitments in contributing and productivity that have been determined and determined by the company. Employee work quality is related to the provision of additional tasks given by superiors to subordinates (Sunyoto, 2015:200). In addition, the company is expected to carry out supervision in the form of monitoring the work produced by employees so that discipline becomes higher in following the rules and regulations that have been set by the company.

PT. Bintang Saudara Semesta Jaya is a company engaged in the sale of dental equipment and supplies. Employees who have good work quality will work in accordance with the company's wishes but in the companies studied the quality of work of employees is not good which can be seen from the tendency to decline in sales in 2019. The decline in sales was also 
influenced by the impact of the COVID-19 pandemic which caused several customers temporarily closed operations. However, gradually with the implementation of the new normal, sales also did not improve (increase) due to the lack of employee creativity in adapting to the new normal era. In this case the target setting is also difficult to achieve.

From the data of PT. Bintang Saudara Semesta Jaya set the achievement of sales targets in January to December 2020 of Rp500,000,000, but employees have not been able to achieve the sales target. The company's sales realization decreased every month. The highest sales achievement occurred in January at 99.23\%. This happens because the company provides promotions in the form of 5\% cash back to customers due to entering the beginning of the year suppliers will offer products with the latest technology. The lowest sales decline occurred in December this was due to the lack of activeness of employees in selling products to customers and finding new customers.

Commitment means an individual's strong acceptance of the goals and values of the organization, and the individual strives and works and has a strong desire to remain in the organization. Workers with high commitment will be more work-oriented. Workers who have high organizational commitment will also tend to be happy to help and be able to work together. Meanwhile, the low work commitment where the company implemented several new policies in 2020 that affected the quality of employee work, as for this work commitment, several employees quit their jobs so that the employee turnover rate in 2020 was quite high where more employees left than recruited.

Based on data in 2020 the employee turnover rate shows the low work commitment of employees to their work. Employees who are accepted to work are not contracted so that employees often stop working without giving notice to personnel. This causes work to be neglected.
Employees who quit reasoned if the compensation given was not in accordance with their work, there was no career path, coworkers were less able to work together so conflicts often occurred.

Supervision is carried out with the intention of supervising whether employees have done work in accordance with what was instructed by the leadership, with supervision activities to minimize work errors and correct work errors. Lack of supervisory activities carried out by superiors on employees of PT. Bintang Saudara Semesta Jaya caused violations committed by employees, for example, lack of control over the physical count of stock items so that the amount of inventory did not match the stock card, frequent delays in delivery of customer orders, the sales department was slow to open sales invoices to the warehouse so that orders were delivered late, sales those who do not reach the target, employees who go home early and the number of products that are returned because they are damaged or expired. This causes losses to the company.

According to Hasibuan (2013:193), discipline is a person's awareness and willingness to obey all company regulations and applicable social norms. Awareness is the attitude of a person who voluntarily obeys all the rules and is aware of his duties and responsibilities. With work discipline, employees are expected to be able to complete their duties efficiently which means they can minimize errors or violations of regulations. Discipline of employees of PT. Bintang Saudara Semesta Jaya towards company regulations is still very lacking, namely there are still employees who are late to the office and negligent in their responsibilities for their work, namely not attending without notification.

From the data, it can be seen that several violations were committed by employees due to lack of employee discipline. Discipline violations usually only get a warning so that it does not cause a deterrent effect for employees. 
Hendra Jonathan Sibarani et.al. Effect of work commitment, supervision, and discipline on the quality of work of employees at PT. Bintang Saudara Semesta Jaya.

The purpose of this study was to determine the effect of work commitment, supervision, and discipline on the quality of work of employees of PT. Bintang Saudara Semesta Jaya, either partially or simultaneously.

\section{LITERATURE REVIEW \\ Effect of Work Commitment on the Quality of Work of Employees}

Organizational commitment is a condition in which an employee intends to work for a particular organization and its goals and maintain membership in that organization (Triatna, 2015:120). According to Wibowo (2016:431) organizational commitment is the feeling, attitude and behavior of individuals who identify themselves as part of the organization, are involved in the process of organizational activities and are loyal to the organization in achieving organizational goals. According to Wahyudi et al. (2021:82) someone who joins the organization is required to have a commitment in himself, because with this commitment, a person's motivation will grow to achieve a goal and if the achievement of these goals is met it will lead to good performance in the employee.

\section{Effect of Supervision on the Quality of Work of Employees}

In general, supervision can be defined as a way for an organization to work effectively and efficiently and to better support the realization of the organization's vision and mission (Fahmi, 2016:151). According to Manullang (2013:177), in the field of production, the supervision can be aimed at the quantity of production results or on the quality or on the company's liquidity. Supervision in the field of time intends to determine whether to produce a product in accordance with the planned time or not. Finally, supervision in the human field with its activities aims H1 H2 H3 H4 to find out whether the activities are carried out according to instructions, work plans or manuals.

\section{Effect of Discipline on the Quality of Work of Employees}

Respect or spiritual attitude of employees towards the rules set and applied in the company (Mulyadi, 2015:48). According to Siagian (2015:305), employee discipline is a form of training that seeks to improve and shape employee knowledge, attitudes and behavior so that these employees voluntarily try to work cooperatively with other employees and improve their work performance. According to Hasibuan (2013:193), stating that good discipline reflects the magnitude of a person's responsibility for the tasks assigned to him. This will encourage work enthusiasm, morale, and the realization of organizational goals.

\section{RESEARCH METHODS}

This research approach is based on a quantitative approach. Quantitative approach is empirical research in which the data is in the form of something that can be calculated. Quantitative approach pays attention to the collection and analysis of data in numerical form (Pandiangan, 2015).

This type of research is a type of quantitative descriptive research. According to Pandiangan et al. (2021), Descriptive research is a type of research that aims to make a systematic, factual and accurate description of the facts and characteristics of the population of a particular area.

The population of this study are all employees of PT. Bintang Saudara Semesta Jaya, which based on data obtained in October 2021, totaled 61 employees from all divisions except managers. According Pandiangan et al. (2018), sampling is the selection of samples based on certain characteristics that are considered to have relevance to the characteristics of the population that have been known previously. The sampling technique used a saturated sample so that the sample used was representative of the entire population, namely 61 people.

Library research of reference sources is a form of research that uses library 
facilities by examining theoretical discussions from various books, articles, and scientific works related to writing (Pandiangan, 2018). In data collection needs, the techniques used are:

\section{Observation and Interviews}

This method is done so that researchers get an overview of the problems that occur in the variables studied.

\section{Questionnaire}

This method is done by making a question questionnaire based on the Likert scale.

This type of data is quantitative data, namely the results of respondents' answers which are quantified and using primary data sources, namely direct distribution of questionnaires.

The data analysis technique used is multiple linear analysis technique. The research used multiple linear regression methods with ordinary least square (OLS) to find out how far the influence of independent variables on dependent variable (Tobing et al., 2018). Hypothesis testing by means of Simultaneous partial (t test), (F test), and coefficient of determination (R2).

\section{RESULT}

\section{Descriptive Statistical Analysis}

The results of this analysis will explain the value of $\mathrm{n}$ as the research sample, the minimum value as the lowest value, the maximum value as the highest value, the mean as the average value and standard deviation.

The results of the data processing will explain the value of the four variables tested in descriptive statistical analysis, namely the variables of work commitment, supervision, discipline, and the quality of work of employees. The explanation for the table tested from the results of data processing can be seen for the work commitment variable with a value of 61 respondents, the mean value of which is 23.9016 with the smallest value of 18 and the largest value of 28 with a standard deviation of 3.00946.

From the results of data processing, it can be seen for the supervision variable with 61 respondents, the mean of 41.4754 with the smallest value of 33 and the largest value of 47 with a standard deviation of 3.36455 .

From the results of data processing, it can be seen for the discipline variable with a sample of 61 respondents, the mean of which is 40.3443 with the smallest value of 30 and the largest value of 46 units with a standard deviation of 2.30857 .

From the results of data processing, it can be seen that the quality of work of employees variable with a value of 61 respondents, the mean of 41.2295 with the smallest value of 35 and the largest value of 47 units with a standard deviation of 3.18011.

\section{Partial (t Test)}

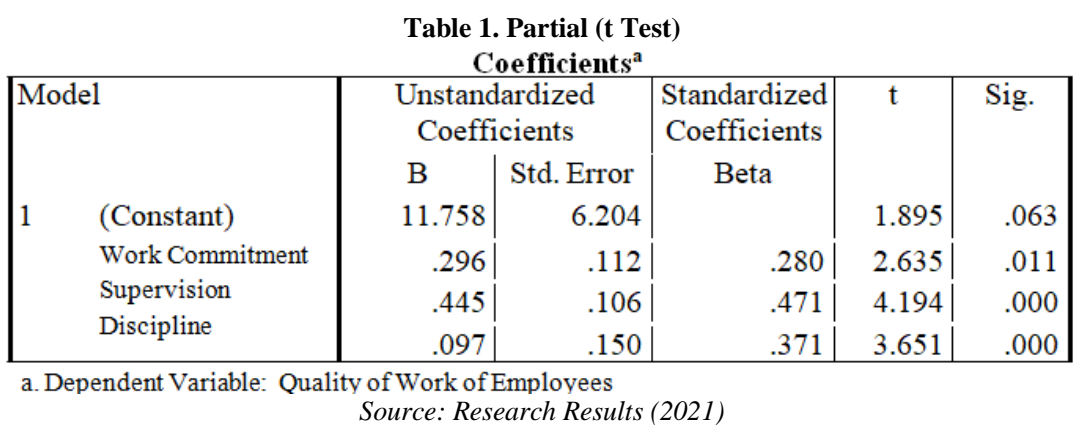

The results of the study indicate that there is effect of work commitment on the quality of work of employees at PT. Bintang Saudara Semesta Jaya. There is effect of supervision on the quality of work of employees at PT. Bintang Saudara Semesta Jaya. There is effect of discipline on the 
quality of work of employees at PT. Bintang Saudara Semesta Jaya.

Continuing engagement allows employees to remain a part of the organization, considering the costs and disadvantages of leaving the company. The level of continuous commitment of an employee does not affect his performance, because basically he does not want to act outside the responsibility and affection for his organization. In this case, the person who is always involved only considers the cost factor (award), but accepting, not attending, or acting on behalf of the organization is not important. For those who have a high level of commitment to sustainability, they are ready to be part of the organization as long as they still enjoy the benefits of working at the company.

Supervision has a relationship with employee performance. With supervision, employee performance will be more controlled. As stated by Kadarisman (2012:192), supervision is a managerial activity carried out with the intention that there are no deviations in carrying out work. A deviation or error occurs or not during the execution of the work depending on the level of ability and skill of the employees.

Work discipline in general plays a major role in improving the quality of work for employees. High work discipline must always be maintained and improved. Employees with good work discipline are expected to do their best to complete the work so that they can provide the best quality work for the company. Disciplined employees are usually punctual and have a high level of responsibility in carrying out established procedures. This is related to the theory of work discipline, according to Soejono (2016:65). The theory states that good discipline reflects an individual's sense of responsibility for the given task. This can encourage an increase in the quality of work and the achievement of company, employee and community goals. In other words, work discipline is the main capital that will determine the level of quality of employee work.

\section{Simultaneous (F Test)}

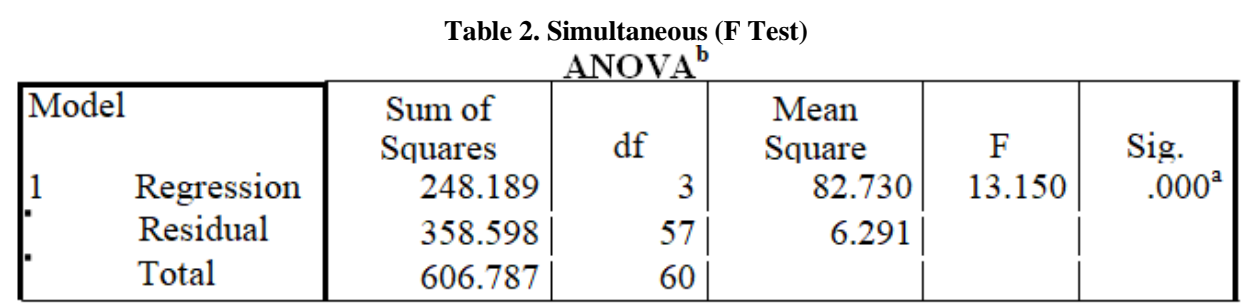

a. Predictors: (Constant), Work Commitment, Supervision, Discipline

b. Dependent Variable: Quality of Work of Employees

Source: Research Results (2021)

Simultaneously there are effect of work commitment, supervision, and discipline on the quality of work of employees at PT. Bintang Saudara Semesta Jaya.

\section{Coefficient of Determination (R2)}

Table 3. Coefficient of Determination (R2)

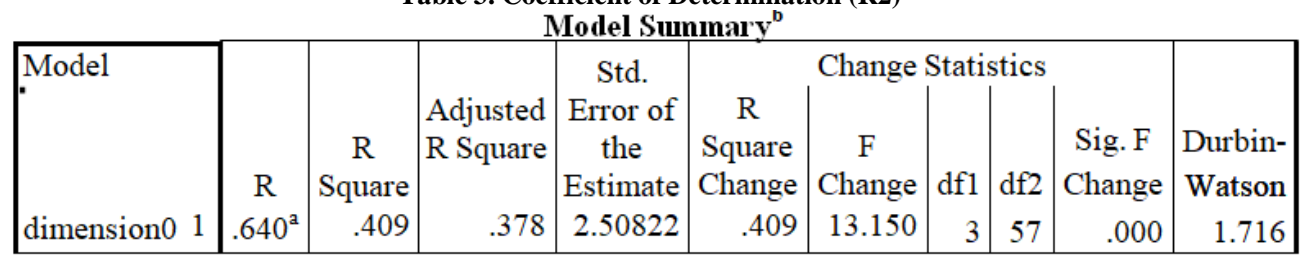

a. Predictors: (Constant), Work Commitment, Supervision, Discipline

b. Dependent Variable: Quality of Work of Employees

Source: Research Results (2021) 
The results of the regression calculation can be seen that the coefficient of determination ( $\mathrm{R}$ square) obtained is 0.409 , this result means that $40.9 \%$ of the quality of work of employees can be explained by the work commitment, supervision, and discipline, while the remaining $59.1 \%$ is explained by other variables which is not researched.

\section{CONCLUSION AND SUGGESTION}

The results of the study indicate that there is effect of work commitment on the quality of work of employees at PT. Bintang Saudara Semesta Jaya. There is effect of supervision on the quality of work of employees at PT. Bintang Saudara Semesta Jaya. There is effect of discipline on the quality of work of employees at PT. Bintang Saudara Semesta Jaya. Simultaneously there are effect of work commitment, supervision, and discipline on the quality of work of employees at PT. Bintang Saudara Semesta Jaya. The results of the regression calculation can be seen that the coefficient of determination ( $\mathrm{R}$ square) obtained is 0.409 , this result means that $40.9 \%$ of the quality of work of employees can be explained by the work commitment, supervision, and discipline, while the remaining $59.1 \%$ is explained by other variables which is not researched.

Suggestions in this study are:

1. The boss of PT. Bintang Saudara Semesta Jaya is expected to improve the quality of discipline for employees and provide better supervision by providing stricter and maximum regulations so that symptoms of irregularities or errors can automatically be prevented and will improve employee discipline.

2. It is better if the supervisory system there needs to be improved, apart from only supervision through Closed Circuit Television (CCTV) monitoring and on the work results, it would be better if the leadership also frequently conducts direct monitoring during the work process so that a good relationship will be created between the leadership and subordinates. The feeling of awkwardness will also disappear and employees will feel ownership of the company and want to improve their best performance.

3. In improving the performance of employees at the company, the company must implement a briefing system for every day to all divisions at PT. Bintang Saudara Semesta Jaya. However, there must be a coordinator for each division, so that everything can be evaluated and find out if the organizational commitment is decreasing. Besides that, you can find out the quality of the company if an evaluation is held every month.

\section{Acknowledgement: None}

\section{Conflict of Interest: None}

\section{Source of Funding: None}

\section{REFERENCES}

1. Fahmi, Irham. (2016). Pengantar Manajemen Keuangan Teori dan Soal Jawab. Bandung: Alfabeta.

2. Hasibuan, Malayu (2013). Manajemen Sumber Daya Manusia. Jakarta: Bumi Aksara.

3. Kadarisman. (2012). Manajemen Pengembangan Sumber Daya Manusia. Jakarta: Raja Grafindo Persada.

4. Manullang, M. (2013). Manajemen Sumber Daya Manusia. Jakarta: Ghalia Indonesia.

5. Mulyadi. (2015). Sistem Perencanaan dan Pengendalian Manajemen. Jakarta: Salemba Empat.

6. Pandiangan, Saut Maruli Tua. (2015). Analisis Lama Mencari Kerja Bagi Tenaga Kerja Terdidik di Kota Medan. Skripsi. Medan: Fakultas Ekonomi dan Bisnis, Program Studi Ekonomi Pembangunan, Universitas Sumatera Utara. https://www.academia.edu/52494724/Analis is_Lama_Mencari_Kerja_Bagi_Tenaga_Ker ja_Terdidik_di_Kota_Medan.

7. Pandiangan, Saut Maruli Tua. (2018). Analisis Faktor-faktor yang Mempengaruhi Penawaran Tenaga Kerja Lanjut Usia di Kota Medan. Tesis. Medan: Fakultas 
Hendra Jonathan Sibarani et.al. Effect of work commitment, supervision, and discipline on the quality of work of employees at PT. Bintang Saudara Semesta Jaya.

Ekonomi dan Bisnis, Program Studi Ilmu Ekonomi, Universitas Sumatera Utara. http://repositori.usu.ac.id/bitstream/handle/1 23456789/10033/167018013.pdf?sequence $=$ 1\&isAllowed=y.

8. Pandiangan, Saut Maruli Tua, Rujiman, Rahmanta, Tanjung, Indra I., Darus, Muhammad Dhio, \& Ismawan, Agus. (2018). An Analysis on the Factors which Influence Offering the Elderly as Workers in Medan. IOSR Journal of Humanities and Social Science (IOSR-JHSS), 23(10), 76-79. DOI: 10.9790/0837-2310087679.

9. Pandiangan, Saut Maruli Tua, Resmawa, Ira Ningrum, Simanjuntak, Owen De Pinto, Sitompul, Pretty Naomi, \& Jefri, Riny. (2021). Effect of E-Satisfaction on Repurchase Intention in Shopee User Students. Budapest International Research and Critics Institute-Journal, 4(4), 77857791.

DOI: https://doi.org/10.33258/birci.v4i4.2697.

10. Sanusi, Anwar. (2014). Metodologi Penelitian Bisnis. Jakarta: Salemba Empat.

11. Siagian, Sondang P. (2015). Manajemen Sumber Daya Manusia. Jakarta: PT Bumi Aksara.

12. Soejono. (2016) Sosiologi Suatu Pengantar. Jakarta: PT Raja Grafindo.

13. Sunyoto, Danang. (2015). Manajemen Sumber Daya Manusia. Jakarta: PT Buku Seru.
14. Sugiyono. (2017). Metode Penelitian Administratif. Bandung: Alfabeta.

15. Tobing, Murniati, Afifuddin, Sya'ad, Rahmanta, Huber, Sandra Rouli, Pandiangan, Saut Maruli Tua, \& Muda, Iskandar. (2018). An Analysis on the Factors Which Influence the Earnings of Micro and Small Business: Case at Blacksmith Metal Industry. Academic Journal of Economic Studies, 5(1), 17-23. https://www.ceeol.com/search/articledetail ?id=754945.

16. Triatna. (2015). Visionary Leadership, Menuju Ekolah Efektif. Jakarta: Bumi Akasara.

17. Wahyudi, T., T.R, Pangabean., \& Pujianto. (2021). Panduan Lengkap Kakao Manajemen Agribisnis dari Hulu hingga Hilir. Jakarta: Penebar Swadaya.

18. Wibowo. (2016). Manajemen Kinerja. Jakarta: Rajawali Pers.

How to cite this article: Hendra Jonathan Sibarani, Dennis Choandy, Suriyani Halim. Effect of work commitment, supervision, and discipline on the quality of work of employees at PT. Bintang Saudara Semesta Jaya. International Journal of Research and Review. 2021; 8(12): 535-541. DOI: https://doi.org/10. 52403/ijrr.20211265 